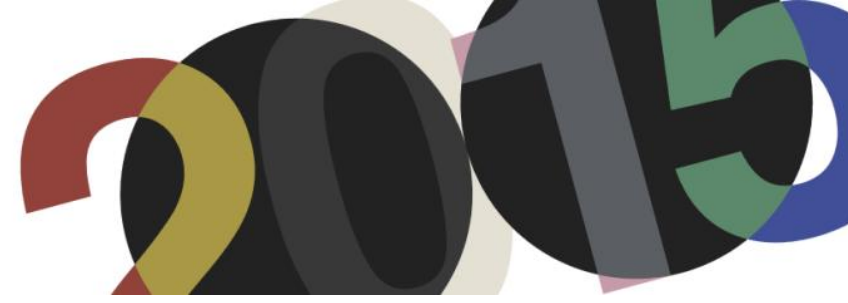

DOI: http://dx.doi.org/10.4995/LC2015.2015.591

\title{
METÁFORAS OBSESIVAS E IDEOGRAMAS [marcas del surrealismo en la construcción del discurso de Le Corbusier]
}

\author{
L. Rojo de Castro
}

Escuela Técnica Superior de Arquitectura de Madrid, UPM

\begin{abstract}
Resumen: El reciente interés académico en el Movimiento surrealista constituye una revisión de largo alcance, habiéndose ampliado el campo de análisis con evidente ambición multidisciplinar. Su estratégica relación con otras disciplinas, la impostación de sus derivas urbanas como prácticas sociales y etnográficas, la profundización en las técnicas de manipulación de la fotografía y la escritura, la naturalización de la fragmentación asociada al montaje y, finalmente, la revisión de la imprecisa naturaleza del objeto surrealista en sus distintas versiones (objet trouvé, objet à réaction poétique, objet-type, ready-made, etc.) y su función seminal en lo contemporáneo, facilitan un escenario de investigación complejo y abierto.

Un escenario en el que la obra de Le Corbusier se dibuja en una nueva perspectiva.

Le Corbusier adoptó técnicas afines al surrealismo, como la fotografía, el montaje y el caligrama, con el objeto de ampliar el significado de los paradigmas asociados a la racionalidad productiva y tecnológica, en particular los que construyen el espacio doméstico. El uso tales medios discursivos y de divulgación asociados con el surrealismo facilitó la contaminación de su discurso con las estrategias desestabilizadoras y conflictivas características del Movimiento.
\end{abstract}

Abstract: The recent academic interest in the surrealist movement is a far-reaching review, having widened the scope of analysis with evident multidisciplinary ambition. Its strategic relationship with other disciplines, the imposture of their urban drifts as social and ethnographic practices, the deepening on the manipulation techniques of photography and writing, the naturalization of fragmentation associated with montage and, finally, the review of the imprecise nature of the Surrealist object in its different versions (objet trouvé, objet à réaction poétique, objet-type, ready-made, etc.) and its seminal role in the contemporary facilitate an open and complex research scenario.

A scenario within which the work of Le Corbusier is perceived in a new perspective.

Le Corbusier adopted techniques related to surrealism, such as photography, montage, automatism and the calligram, in order to expand as well as undermine the meaning of canonical paradigms associated to productive and technological rationality, in particular those related to the domestic milieu. The use of such display of discursive instruments facilitated the contamination of his editorial and architectural work with the destabilizing and conflicting strategies that characterize the Movement.

Palabras Clave: Surrealismo, metáforas obsesivas, montaje, automatismo, analogía, arbitrariedad.

Keywords: Surrealism, obsessive metaphors, montage, automatism, analogy, arbitrariness.

\section{Introducción}
“Todavía vivimos bajo el imperio de la lógica, y precisamente a eso quería llegar. Sin embargo, en nuestros días, los procedimientos lógicos tan solo se aplican a la resolución de problemas de interés secundario." 1

André Breton, 'Primer Manifiesto Surrealista'

\footnotetext{
1 Breton, André: Manifeste du surréalisme. Paris: Gallimard, 1924. 2ª Ed. 1966. Traducción: Manifiestos del Surrealismo. Visor Libros, Madrid, 2002, pp. 20
} 
Los Surrealistas reconocieron su hábitat más afín en la ciudad, -París en particular-, apropiándose de sus imágenes para construir el escenario de una transformación radical de la experiencia urbana -de los ciclos cotidianos, la ocupación de los espacios públicos o de la arquitectura como soporte. Expusieron, bajo la aparente continuidad de los hechos, una versión distinta aunque construida de objetos familiares, lugares emblemáticos y fragmentos de la memoria colectiva, esforzándose en revelar la 'anormalidad en la normalidad'.

Ajenos a la utopía o los modelos abstractos, hicieron de la ciudad el laboratorio de sus experimentos, alcanzando un nivel de infiltración al que era difícil sustraerse. Creyeron descubrir en la heterogénea e impredecible actividad del paisaje urbano los elementos para activar otro modo de percepción predicado en la continuidad onírica, la desconexión del automatismo y el azar de los encuentros involuntarios.

Y pertrechados con tales herramientas, se propusieron superar la contraposición entre las cualidades simbólicas y físicas del espacio imaginario frente a las del espacio real o, dicho de otra manera, la oposición clásica entre sueño (irracional) y acción (racional).

Pero, a diferencia de otras Vanguardias, no aspiraron a una transformación material/literal de la realidad que los rodeaba, sino una intensificación de su relación con esta, apropiándose de las técnicas del flâneur y del coleccionista -caracteres urbanos propios de su tiempo moderno- haciendo de la experiencia urbana el soporte de su identidad.

Con tal fin, provistos del ojo mecánico del fotógrafo/voyeur y de las técnicas de des-familiarización del etnógrafo/coleccionista, se emplearon a fondo en perturbar la integridad y estabilidad de los códigos, fueran estos urbanos, sociales, morales o visuales. La experiencia urbana y el desmembramiento de sus soportes simbólicos, iconográficos y semánticos se identifican en el ideario surrealista para construir otra realidad a partir de sus elementos constitutivos -desmembrados, desfigurados o desplazados- por medio de procesos ajenos a la creación o la novedad.

\section{“...el esfuerzo humano, que tiende a variar sin cesar la disposición de elementos existentes, no puede ser aplicado a producir un solo elemento nuevo." 2}

Las propuestas surrealistas para el 'embellecimiento irracional de París, ${ }^{3}$-cuya vocación era desvelar los escenarios surreales subyacentes bajo la aparente continuidad de las apariencias-, se caracterizan por la constante alteración de sus referencias emblemáticas, así como la desestabilización de su memoria colectiva. La manipulación y el trastorno de lo conocido permitía romper el sistema cotidiano de relaciones -el entorno estable de referencias-, emancipándose del principio de realidad pero sin escapar de la misma.

Así lo ponen de manifiesto los relatos urbanos de Louis Aragon y André Breton. Tanto en Le paysan de París (1926) como en Nadja (1928), los personajes deambulan sin aparente propósito o argumento por una ciudad que se esfuerzan en no reconocer. Una ciudad desmembrada en múltiples fragmentos y sometidos a una azarosa espera, aguardando ser 'descubiertos' [trouvaille], recuperados y, solo entonces, dotados de un nuevo significado y función construido en la azarosa circunstancia del encuentro.

\footnotetext{
2 Breton, André (1924): opus cit

3 Eluard, Paul: 'Sur certaines possibilités d'embellissement irrationnel d'une ville'. Surréalisme au Service de la Révolution $n^{\circ} 6$. París 1933
} 
Sin embargo, se ha dicho que la arquitectura no formaba parte de las preocupaciones del surrealismo, que sus intereses se centraban en las artes plásticas, la fotografía y la literatura. ${ }^{4} \mathrm{Y}$, aunque es razonable afirmar que no hay una arquitectura surrealista como tal, como tampoco un modo surrealista de hacer arquitectura, recientemente se han aportado instrumentos alternativos para comprender en profundidad la compleja relación entre surrealismo y arquitectura.

Desde este nuevo punto de vista, y a pesar de la inexistencia de una arquitectura surrealista, la arquitectura sería el instrumento adecuado para cuestionar las estructuras estables de las convenciones, la representación, el lenguaje, la ocupación y producción del espacio, de la ciudad y de sus imágenes o la producción de objetos e ideas, las prácticas sociales, la función simbólica de la técnica, etc. ${ }^{5}$

En este nuevo escenario crítico, la arquitectura -la ciudad- no sería el fin en sí mismo sino el instrumento, la herramienta del surrealismo. La arquitectura sería el 'medio' y no el mensaje: tal es el cambio fundamental de paradigma crítico.

Así lo constatan los escritos de Apollinaire, Breton o Aragon, en los que la actividad surrealista se concentra en dos escenarios paradigmáticos del cambio de Siglo: el interior doméstico como instrumento de construcción de la identidad privada, y el paisaje urbano, en el que se expresan y representan los conflictos de una vida moderna en gestación. Y así lo corrobora Walter Benjamín, cuyo escepticismo con el diletantismo surrealista no le impide reconocer la función estructural y alegórica de la desestabilización de ambos paradigmas.

El reciente interés académico en el Movimiento surrealista constituye una revisión de largo alcance, habiéndose ampliado el campo de análisis con evidente ambición multidisciplinar. ${ }^{6}$

Su estratégica relación con otras disciplinas, la impostación de sus derivas urbanas como prácticas sociales o etnográficas, la profundización en las técnicas de manipulación de la fotografía y la escritura, la naturalización de la fragmentación asociada al montaje y, finalmente, la revisión de la imprecisa naturaleza del objeto

\footnotetext{
${ }^{4}$ Nos referimos al 'estado de la cuestión' a final de los 80, cuando la revista inglesa AD publicó un número monográfico sobre arquitectura y surrealismo editado y dirigido por D. Vaseley: 'Surrealism and Architecture'. Architectural Design $n^{o}$ 5\&6. Londres, UK, 1978

5 “... a pesar del aparente desinterés de los surrealistas por la arquitectura, la arquitectura parecería el más prometedor de los instrumentos para una verdadera práctica surrealista." Vidler, Anthony (2003): Fantasy, the Uncanny and Surrealist Theories of Architecture', keynote speech given at the conference "Fantasy Space: Surrealism and Architecture", Manchester, Whitworth Art Gallery, September 12, 2003. El interés de A. Vidler por la relación entre surrealismo y arquitectura viene de lejos, sirva como muestra el libro The Architectural Uncanny: Essays in the Modern Unhomely. Cambridge, Mass: MIT Press, 1992

${ }^{6}$ Sirvan de ejemplo los siguientes libros, listados por orden alfabético: Adamowicz, Elza: Surrealist Collage in Text and Image. Dissecting the exquisite corpse. Cambridge University Press, 1988. Caws, Mary Ann: The surrealist look. An erotic of encounter. Cambridge, Mass: MIT Press, 1997. Clifford, James: The Predicament of Culture. Twenty-Century Ethnography, Literature and Art. Cambridge, Mass: Harvard University Press, 1988. Fijalkowski, Krzysztof: Un salon au fond d'un sac. The domestic spaces of surrealism. Surrealism and Architecture. New York: Ed Thomas Mical, Routledge, 2005. Foster, Hal: Compulsive Beauty. Cambridge, Mass: MIT Press, 1993. Krauss, Rosalind: Corpus delicti, L'Amour fou, New York/London: Abbeville Press, 1985. Krauss, Rosalind: The optical unconscious. Cambridge, Mass: October Book, MIT Press, 1993. Krauss, Rosalind \& Bois, Yve-Alain: Formless. A user's guide. New York: Zone Books. 1997. Malt, Johanna: Obscure Objects of Desire. Surrealism, Fetishisim and Politics. Oxford University Press, 2004. Mileaf, Janine: Please Touch. Dada and Surrealist objects after the readymade. Lebanon, NH: Darmouth College Press, 2010. Tythacott, Louise: Surrealism and the Exotic. New York: Routledge, 2003
} 
surrealista en sus distintas versiones (objet trouvé, objet à réaction poétique, objet-type, ready-made, etc.) y su función seminal en lo contemporáneo, facilitan un escenario de investigación complejo y abierto. Un escenario en el que la obra de Le Corbusier se dibuja en una nueva perspectiva.

Le Corbusier compartió el espacio y el tiempo con los surrealistas, el inquieto París de la posguerra. Pero también las técnicas productivas con las que inundaron el ambiente social, intelectual y cultural de la ciudad: la afición por desplazar objetos y conceptos en el espacio y en el tiempo fuera de su lugar de origen, por forzar la aproximación de realidades dispares y ajenas, o por manipular estructuras estables -como el lenguaje, el marco, la geometría, la anatomía o el espacio doméstico- para erosionar sus fundamentos hasta la desfiguración, pero cuidándose de no perder la referencia de los mismos.

Adoptó otras técnicas afines al surrealismo, como la fotografía, el montaje y el caligrama, con el objeto de ampliar el significado de los paradigmas asociados a la racionalidad productiva y tecnológica, en particular los de la máquina. Y las empleó para construir, finalmente y a través de la edición y manipulación de textos e imágenes en libros, conferencias, revistas y otros medios de divulgación, una versión deformada de su propia obra.

Y es precisamente el uso simultáneo de tal conjunto extenso de medios discursivos y de divulgación, y su particular utilización por el autor, lo que facilitó la contaminación de su discurso con las estrategias desestabilizadoras y conflictivas del surrealismo y que nos proponemos analizar.

\section{EI montaje}

Así ocurre en los fotomontajes con los que Le Corbusier ilustra la potencial transformación de la casa y la ciudad -de lo doméstico y lo urbano- con los nuevos principios maquinistas, pero que comparten con el surrealismo técnicas y recursos tanto conceptuales como productivos.

En una sola operación gráfica y literal, el imponente 'Aquitania' se incrusta no sin violencia en la ciudad para demostrar su monumental superioridad como icono y como paradigma: un objeto convexo cuya potente lógica interna, predicada en la flotación, le permite ser independiente del lugar y de su contexto. Y, como consecuencia, las convenciones de la arquitectura se sustituyen por la ley de Arquímedes, un principio matemático universal, racional por definición, capaz de producir 'objetos técnicos' dotados de una coherencia interna autónoma y objetiva.

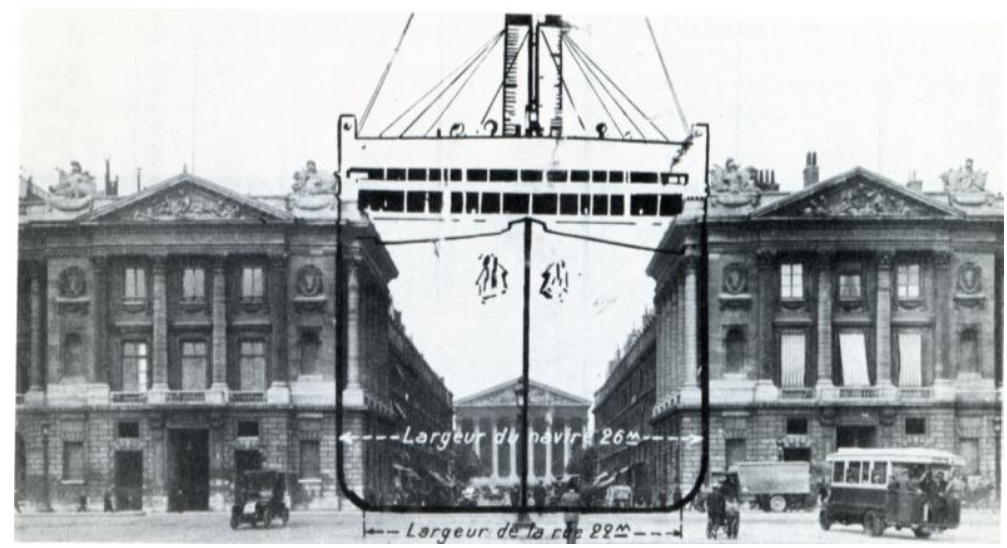

1. Le Corbusier (1935): 'La Ville Radieuse, éditions de l'Architecture d'Aujourd'hui', Collection de l'équipement de la civilisation machiniste, Boulogne-sur-Seine, pag 123 FLC-ADAGP 
Sin embargo, a pesar de la vocación racional contenida en la admiración por el 'parquebote', su imagen superpuesta en la Plaza de la Concordia nos enfrenta a un desplazamiento icónico de gran envergadura cuyas implicaciones exceden las meramente funcionales o tecnológicas.

La fragmentación asociada con esta operación, -el desplazamiento de un objeto fuera de su contexto y su ubicación en un lugar ajeno, fuera de escala y de relación-, traslada a la construcción de la ciudad las técnicas discontinuas del montaje tal y como los concebían los surrealistas: no como operación material sino como una actividad eminentemente semiótica, consistente en la manipulación y desplazamiento de mensajes icónicos y verbales previamente formados o emitidos.

El trasatlántico representa el paradigma de la transformación tecnológica asociada al pensamiento racional: es un producto de la 'ley de la causa y el efecto', en palabras de Le Corbusier. Sin embargo, su abrupta ubicación en la Plaza de la Concordia responde a las técnicas surrealistas del shock, de los desplazamientos oníricos y de la desestabilización de las convenciones físicas, sociales o simbólicas. Y, lo que es más significativo, la desestabilización de la lógica invocada por el propio Le Corbusier.

Y, sí es inevitable relacionarlo con el redimensionamiento de la arquitectura por medio de las leyes de la nueva eficacia industrial y productiva, igualmente ofrece coincidencias sustanciales con las propuestas desestabilizadoras del paisaje urbano realizadas por André Breton y sus compañeros de 'deriva'.

A pesar de sus fundamentales desencuentros con los surrealistas, en los fotomontajes de Le Corbusier puede detectarse una paradójica coincidencia con la máxima de Breton:

“...se considera menos interesante una estatua en un pedestal que en un hoyo." 7

Es decir, la experiencia de todo objeto o cuerpo conocido se ve intensificada como consecuencia del desplazamiento y la descontextualización.

En el fotomontaje realizado para ilustrar el texto 'Tres Advertencias a los señores arquitectos', publicado en el primer número de L'Esprit Nouveau, la imagen del Aquitania se recorta contra le Tour Saint-Jacques, la catedral de Notre Dame, el Arco de Triunfo y la Ópera, precisamente los monumentos elegidos por la revista Le Surréalisme au Service de la Révolution en su cuestionario a los miembros del Movimiento Surrealista para proponer un 'embellecimiento irracional' de París a través de la alteración, modificación o desfiguración de sus monumentos más emblemáticos.

La indirecta respuesta de Le Corbusier al cuestionario de la revista surrealista -al que no había sido invitado a participar- es rotunda: la trivialización de los monumentos enfrentados 'vis a vis' a la imagen imponente y superpuesta de un objeto fuera de lugar y de contexto y cuya coherencia interna no es más relevante que su arbitrario desplazamiento.

Definitivamente, su presencia en la imagen no responde a su funcionalidad como máquina u objeto técnico, sino como icono desestabilizador, como fetiche de significado inestable fruto de la descontextualización y el montaje. Varado en la Plaza de la Concordia, el Aquitania es una ruina contemporánea.

\footnotetext{
${ }^{7}$ Breton, André: Ouvrés complètes II. Paris, Gallimard, 1992. pag 305 [‘...une statue est moins intéressante à considérer sur une place que dans une fosse.']
} 
En el discurso de Le Corbusier, el 'Aquitania' y sus potentes imágenes se asemejan tanto al instrumento técnico predicado en la lógica productiva como al objeto surrealista descrito por Breton:

"En cuanto a la experiencia del objeto, su significado convencional se subordina a su valor dramático, es decir, a su poder de evocación y su imagen más pintoresca." 89

Contaminada por los modelos del objet chance y el automatismo, la analogía, en manos de los surrealistas, abre el discurso al azar de las relaciones arbitrarias, pero controladas dentro de los límites estructurales de una sintaxis o de una anatomía, poniendo de manifiesto que su propósito no es mostrar conexiones o parecidos existentes -por poéticos que estos sean-, sino construir otros sistemas de relaciones que des-familiaricen, transformen o modifiquen nuestra percepción y entendimiento del mundo que nos rodea sin necesidad de alterarlo físicamente.

Aragón escribe en 'El desafío a la pintura' (1930):

"Una lámpara eléctrica se transforma para Picabia en una jovencita. Aquí vemos que los pintores utilizan los objetos verdaderamente como palabras." 10

No se trata, sin embargo, de un mero intercambio de objetos o de su mecánico desplazamiento en el espacio, en el tiempo o en la imaginación. Estamos ante la distorsión de los códigos de significación, como afirma Foucault, hasta el punto de superar las diferenciaciones más fundamentales entre la imagen y la palabra, precisamente aquellas que le permiten a Le Corbusier hablar y dibujar simultáneamente, expresarse indistintamente con textos y figuras, con formas y palabras, ideas e ideogramas.

La manipulación del Aquitania adelanta la aplicación de las técnicas del montaje y la distorsión de la analogía no solo a la construcción de la realidad y de la ciudad, sino también y fundamentalmente, del discurso. Por ello, no pueden ser reducidas a meras analogías maquinistas ni figuras poéticas.

En una inadvertida coincidencia con las técnicas surrealistas, las imágenes construidas por Le Corbusier visuales, literarias o metafóricas-, y puestas en circulación en libros, conferencias y revistas, no se soportan en parecidos o continuidades reales, sino en la construcción, por medio de las técnicas del montaje, de conexiones visuales o semióticas que, por su naturaleza imprevista o arbitraria, incentivaran relaciones potenciales ajenas a los objetos y su función, a su identidad u origen.

"La imagen es una creación pura del espíritu, y no puede nacer de la comparación sino del acercamiento de dos realidades más o menos lejanas. Cuanto más lejanas y escasas las concomitancias entre ambas realidades objeto de aproximación, más fuerte será la imagen..." 11

\footnotetext{
8 Le Corbusier: Vers une architecture. París: Flammarion, 1923. Reeditado 1991, pag 92

9 Breton, André: Surrealism and Painting. París: Editions Gallimard, 1928. MFA Publications, Boston 2002

${ }^{10}$ Aragon, Louis (1930): Los collages. El desafío a la pintura. Madrid, Editorial Síntesis,

${ }^{11}$ Reverdy, Pierre: Nord-Sud No Marzo, París, 1918
} 
Los surrealistas se caracterizan por intensificar la experiencia por medio de relaciones metafóricas y metonímicas en las que las intersecciones analógicas construidas entre los elementos tienden a cero. Y es precisamente la falta de coherencia entre los elementos involucrados en la relación analógica lo que obliga al espectador a comprometerse, y a la realidad a deformarse.

Una intensificación de la experiencia que diseminan tanto por el espacio de la ciudad como del conocimiento, a la producción de imágenes y de textos, en la poesía y en la conversación de café. Y, como consecuencia de esta práctica, barcos y ciudades, coches y casas, urinales y objetos domésticos, tipografías, titulares y fragmentos de catálogos comerciales se ensamblan inesperadamente en un discurso construido de conexiones cuya arbitrariedad es altamente productiva.

"La llave de la prisión mental solo se encuentra en las rupturas que nos traen otros modos irrisorios de conocer: reside en el juego libre e ilimitado de las analogías...", escribe Breton. ${ }^{12}$

Las imágenes construidas por Le Corbusier se apropian de tales mecanismos, construyendo la nueva arquitectura con medio de fragmentos literalmente extraídos de otras áreas o disciplinas ajenas a la arquitectura, objets trouvés procedentes de escenarios tan dispares como la producción industrial, los nuevos útiles de oficina, la ingeniería naval o los artefactos más precisos producidos por la tecnología bélica. Conexiones improbables, incluso forzadas, cuya extrema potencia icónica, procedente de una obsesión recurrente, se asocia con la inestabilidad semántica propia de la paradoja y ajena a la razón.

Bajo la influencia de la sensibilidad surrealista, tanto la vida urbana de París como el discurso de Le Corbusier se saturan de fetiches, objetos cuyo significado trasciende su cualidad y apariencia material, su función aparente o convencional, para convertirse en iconos sometidos a constante deformación.

\section{El caligrama}

La página 27 del libro Une Maison, un Palais $(1928)^{13}$ muestra una fotografía del lago Leman tomada desde el aire. En ella se muestran una vía del ferrocarril que corre paralela y junto al lago, la superficie plana del agua y la densa red de bancadas escalando la montaña. Al fondo un imponente pico rocoso se levanta cerrando con rotundidad el espacio de la fotografía. En el centro de la imagen un barco atraviesa la neblina, navegando junto a la orilla por la que discurren las vías del tren.

Al pie de la foto Le Corbusier escribe: 'une maison'. Sin embargo, en la imagen no aparece una casa. De hecho, la arquitectura como tal está ausente.

\footnotetext{
${ }^{12}$ Breton, André: Le Surréalisme et la peinture. París, Gallimard, 1965. ['La clé de la prison mentale ne peut être trouvée qu'en ruptures avec ces façons dérisoires de connaître: elle réside dans le jeu libre et illimité des analogies.']

${ }^{13}$ Le Corbusier: Une Maison-une Palais. París: Editions Convences, 1928
} 


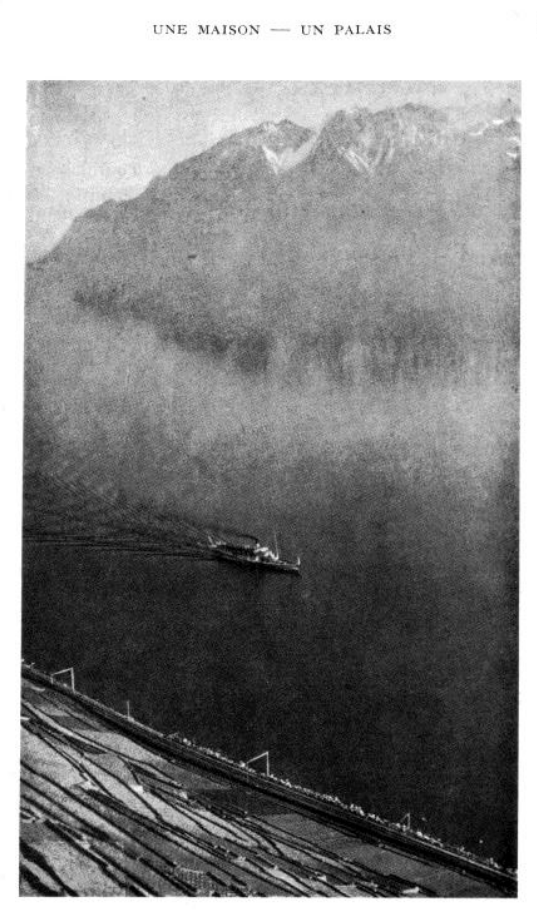

2. Le Corbusier (1928) 'Une Maison, un Palais’ Éditions Crès Collec. "L'Esprit Nouveau", Paris, pag 27 FLC-ADAGP

Las dos palabras escritas bajo de la fotografía nos enfrentan a una paradoja similar a la planteada en el caligrama 'la trahison des images (1928) ${ }^{14}$, cuidadosamente delineado por Magritte.

La aparente continuidad entre ambos medios de expresión -imagen y texto-, confiada a la figura integradora del marco que las contiene - la página del libro-, revela una primera y fundamental fractura: aquello que aparece en la imagen no es una casa, es un barco. Si Magritte escribió bajo el dibujo de la pipa "ceci n'est pas une pipe", aquí debería escribirse, con la misma letra redonda y escolar, "ceci n'est pas une maison."

Atendiendo al exhaustivo análisis realizado por Foucault, ${ }^{15}$ el mensaje del caligrama, icónico y enfático, nos enfrenta con la duda de sí estamos llamados a mirar o a leer para, finalmente, darnos cuenta que el mensaje no está completo, ya que carece de suficiente unidad y articulación para ser descodificado de forma clara y unívoca. $\mathrm{El}$ 'espacio coherente de la lectura' se ve alterado por la analogía construida entre el barco y la casa, en la que las intersecciones entre los elementos comparados son mínimas, la conexión tan tenue que debe ser necesariamente intensificada por el lector.

Estamos, de hecho, ante una metonimia disociativa, una metáfora obsesiva construida entre dos objetos a pesar de sus fundamentales diferencias: la casa y el transatlántico. El uno, estable y estático; el otro, ajeno a un lugar y en constante movimiento; el primero, un instrumento básico en la formación material, social y cultural de la identidad y la memoria colectiva; el segundo, un artefacto tecnológico predicado en la eficacia técnica y la inestabilidad propia de la flotación.

\footnotetext{
${ }^{14}$ René Magritte, 1928. Óleo sobre lienzo. 63 x 93 cm. Los Ángeles County Museum of Art, LA

15 Foucault, Michel: Ceci n'est pas une pipe. Montpellier: Fata Morgane, 1973. Traducción: Esto no es una pipa. Barcelona, Editorial Anagrama, 1981
} 
Si nos atenemos al parecido en la localización - una casa en la orilla del lago-, podemos aventurar que Le Corbusier está pensando en la Petite Maison. Sin embargo, no son más que especulaciones que intentan cerrar la fractura inscrita en el caligrama, reconstruir una continuidad entre texto e imagen para cerrar la incertidumbre que se cierne sobre el lenguaje mismo.

Para aquellos 'ojos que no ven, ${ }^{16}$ la contradicción contenida en el caligrama facilita la intensificación del mensaje a través de la doble condición icónica y metonímica del barco, cuya función es iniciar una cadena de asociaciones, directas e indirectas, con otros objetos o ideas, introduciendo un alto grado de indeterminación a pesar de su potente concreción física.

La analogía así concebida está inscrita en la raíz del surrealismo, caracterizada por multiplicar exponencialmente las relaciones al no requieren del fundamento de un parecido o de una conexión estructural. La analogía surrealista potencia la arbitrariedad en las conexiones para intensificar el significado, adentrándose en terrenos vedados al control de las convenciones disciplinares o de la razón. Y, siguiendo de hecho las técnicas del 'Cadavre Exquis ${ }^{,}{ }^{17}$ permite construir un cuerpo híbrido formado con partes inconexas, más propio del autómata que de la máquina.

Perdida la necesidad de una justificación intrínseca o extrínseca en la analogía, el poeta surrealista Paul Eluard estaría en lo correcto: Todo es comparable a todo.

Y así ocurre en la portada del segundo capítulo de L'Art décoratif d'aujourd'hui (1925), donde el montaje de imagen, tipografía y texto no deja lugar a la duda: la maquetación de la página guarda las marcas de la edición comercial contemporánea -los catálogos de venta que interesaron tanto a Max Ernst como a Le Corbusier, pero también las marcas del surrealismo: los recursos del collage y la escritura automática que permiten unir 'sobre un soporte inapropiado, ${ }^{18}$ diversos medios de expresión y técnicas de representación para provocar relaciones fortuitas e inconexas capaces de desvelar y transmitir ideas con mayor rotundidad.

La edición de L'Art décoratif d'aujourd'hui conserva las marcas provenientes de las agrupaciones indexadas de los catálogos comerciales que construyen el discurso por agregación, así como de la construcción de mensajes icónicos propios de la publicidad urbana y la prensa diaria, o de la naturalización del montaje a partir de fragmentos de la ciudad moderna.

Pero, en su potencia y refinamiento, muestra igualmente las marcas del surrealismo: La apariencia de una sintaxis en la tipografía, el orden vertical de la lectura y la potente figura del marco anuncian una legibilidad que finalmente no se proporciona, poniendo en cuestión las convenciones de la lectura, la sintaxis y el marco.

La sinuosa figura del bidé introduce, en el discurso institucional del museo y de las artes decorativas, un objeto cotidiano vinculado al espacio privado del aseo, la representación de las formas antropomórficas y al cuerpo femenino - el fetiche surrealista por derecho.

\footnotetext{
${ }^{16}$ Le Corbusier (1923): Ibid. pag 65

${ }^{17}$ Brotchie, Alastair: A book of Surrealist games. London: Redstone Press, 1991.

${ }^{18}$ Lucien Duchase, Isidore, Conde de Lautréamont (1896): Los Cantos de Maldoror, Madrid: Editorial Pretextos, 2000
} 
El bidé - un signo aislado que flota en la superficie blanca de la página- posee las cualidades de 'objet trouvé, operando simultáneamente como 'objet type' -predicado en la racionalidad del objeto instrumental- y como fetiche sexual -asociado a la irracionalidad incontrolada del subconsciente.
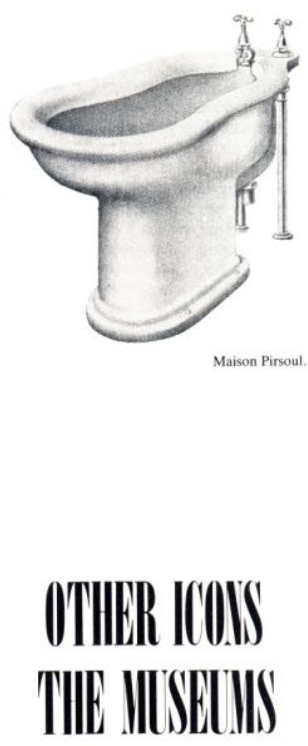

There are good museums, and bad. Then there are those with the good and bad together. But the museum is a sacred entity which debars judgement.

3. Le Corbusier (1925) 'L'Art décoratif d'aujourd'hui', Éditions Crès, Collec. "L'Esprit Nouveau” pag 15 FLC-ADAGP

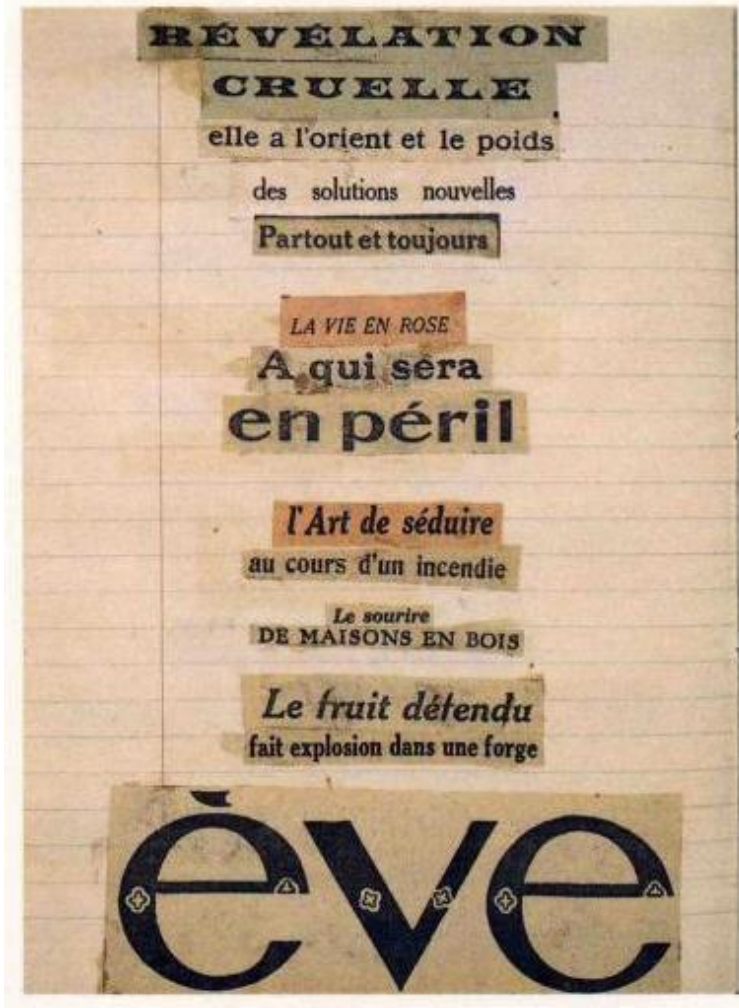

4. André Breton (1924): 'Poème' 
Entendido como 'objet type', reafirma las cualidades instrumentales y funcionales de los objetos racionalmente concebidos como 'extensión' y suplemento de la anatomía del cuerpo y fabricados con las técnicas productivas características de la industrialización; como 'fetiche', representa la difícil construcción de la identidad privada en el espacio público y abierto de la nueva arquitectura y de la transparencia social.

Su presencia en la página como icono capaz de desestabilizar la institución del museo es el resultado de un desplazamiento desde el espacio privado de lo doméstico, asociado al cuerpo femenino, al discurso disciplinar de la arquitectura contemporánea, pero aún lo es más la desconexión entre la imagen y el texto situado al pié de la imagen: “Outres icones. Les musées” [Fig 3]

No en vano, el bidé es uno de los 'objetos contemporáneos' que deberían exhibirse en el 'verdadero museo', tal y como lo describe Le Corbusier en L'Art décoratif d'aujourd'hui. El verdadero museo es un fragmento de la realidad formado, a su vez, de otros tantos fragmentos, un instante de la ciudad en el que se acumulan los instrumentos de la vida diaria.

\section{"Un lugar que lo contenga todo" 19}

Su colección no está formada por obras de arte, objetos valiosos o piezas excepcionales. Muy al contrario, acumula sombreros y zapatos junto a bombillas, bidets y sillas Thonet.

El Museo imaginado por Le Corbusier es más parecido al mercadillo de Saint-Ouen que al Louvre. O quizá su modelo fuera el Museo Etnográfico del Trocadero, cuya colección de artefactos tribales constituía, al igual que el mercadillo, el modelo alegórico surrealista no solo de la experiencia de lo urbano, sino de toda experiencia. Ambos lugares, el Trocadero y Saint-Ouen, fueron los verdaderos laboratorios de experiencias surreales.

Los libros escritos, montados y editados por Le Corbusier, a pesar de su pedigrí racionalista y enérgica voz de manifiesto a favor de la transformación de la realidad con los nuevos procedimientos industriales de producción y reproducción, se muestran finalmente contaminados por las técnicas del surrealismo: las conexiones paradójicas, el montaje y el azar automático.

Así ocurre en la página 31 de Ver une architecture. ${ }^{20}$ Su edición se asemeja a los poèmes objet, 'construidos' en el círculo de Breton como juegos colectivos usando frases sueltas y descontextualizadas, titulares de periódicos o proverbios, unidos azarosa o automáticamente. Es el caso de Poème, ${ }^{21}$ formado por agregación de frases impresas, tomadas de libros y periódicos, cortadas y pegadas sobre el papel. [Fig 4]

El uso de la yuxtaposición como mecanismo dominante dificulta la intención inicial de 'leer' el poema como unidad lingüística y de significado, tropezándonos constantemente con sus fracturas materiales y semánticas. El

\footnotetext{
${ }^{19}$ Le Corbusier: L'Art décoratif d'aujourd'hui. París : Editions G Cres, 1925. pag 17

${ }^{20}$ Le Corbusier (1923): Ibid

21 Breton, André (1924): Poeme. Según Alastair Brotchie (1991), el 'poème objet' es uno de los juegos surrealistas, en parte como escritura automática y en parte como objeto surrealista. Como tal, se define como un poema en el cual una parte de los términos o elementos son tratados como objetos, en lugar de cómo palabras. También puede considerarse como la aplicación de la técnica del 'cadavre exquis' a la escritura o la construcción de un texto.
} 
collage surrealista es, en definitiva, una actividad eminentemente semiótica -más que una operación material o formal- consistente en la distorsión de mensajes icónicos y verbales previamente formados o emitidos.

Aun siendo paradójico, puede afirmarse que la lógica aplastante del discurso maquinista de Le Corbusier se construye con técnicas compartidas con los collages surrealistas de Max Ernst y de la escritura automática propuesta por Breton: uniendo fragmentos extraídos directamente de la realidad, de los catálogos comerciales e industriales, de imágenes icónicas del pasado, aproximadas en una aparente continuidad que no deja trazas de sus fracturas, predicada no en la articulación coherente sino en la conexión arbitraria.

\title{
4. La analogía
}

En el Primer Manifiesto del Surrealismo, publicado en 1924 y contemporáneo de los textos en L'Esprit Nouveau, André Breton aborda la tarea de describir las cualidades de las imágenes surrealistas.

\begin{abstract}
“Los innumerables tipos de imágenes surrealistas exigen una clasificación', escribe Breton. 'No voy a ocultar que para mí la imagen más fuerte es aquella que contiene un alto grado de arbitrariedad, aquella que más tiempo tardamos en traducir a lenguaje práctico, sea debido a que contiene en si una enorme dosis de contradicción, sea a causa de que uno de sus términos esté curiosamente oculto, sea porque tras haber presentado la apariencia de ser sensacional se desarrolla débilmente, sea por porque de ella se derive una justificación formal irrisoria, sea por que pertenezca a la clase de las imágenes alucinantes, sea porque preste de un modo muy natural la máscara de lo abstracto a lo que es concreto, sea por todo lo contrario, sea porque implique la negación de alguna propiedad física elemental, sea porque dé risa." 22
\end{abstract}

En su deambular por la ciudad, el fotógrafo surrealista -mitad flâneur mitad coleccionista- intensifica la atención sobre lo que le rodea, iluminando en encuentros fortuitos objetos capaces de reavivar una imagen, un destello, un recuerdo, un temor o una obsesión.

La fotografía es el instrumento para capturar aquellos fragmentos de la realidad que operan como agitadores de la conciencia, de la memoria y de las convenciones. Al igual que la 'escritura automática', la inmediatez mecánica de la fotografía, ajena a las limitaciones de la representación, se emplea como mecanismo de introspección que facilita la exposición de los conflictos entre objeto y sujeto, entre el ciudadano y la ciudad, o entre el hombre y la nueva civilisation machiniste.

Fotografía y escritura automática permiten ver y escribir sin las limitaciones de una construcción cultural o social. Por ello, Breton afirma:

\section{"La escritura automática es la verdadera fotografía del pensamiento." 23}

El ojo de Brassaï constituye un ejemplo paradigmático de la visión surreal de la ciudad. Y no sólo por su afición a retratar aspectos sórdidos y ambientes marginales de la ciudad: sus imágenes introducen un modo de mirar contrario a toda naturalidad.

22 Breton, André: Manifeste du surréalisme. París: Gallimard, 1924

23 Bretón, André (1924): Ibid 
Se apropia de escenas y objetos que encajaban intencionadamente en la categoría del cliché urbano o doméstico, forzando su desfiguración o tornando irreconocible lo familiar -bien por el exceso de proximidad, por la tergiversación del punto de vista o centrándose con tal grado de detalle, de obsesión, sobre los objetos, que es imposible reconstruir su contexto-, alterando los soportes de la memoria colectiva y de la identidad.

El ojo de Brassaï -su cámara- no actúa como un órgano biológico predispuesto a restituir una razón coherente en la apariencia de las cosas, sino como una máquina de aislar, desmembrar y fragmentar, enfrentándonos a un enigma tras otro.

En sus manos, la fotografía es un mecanismo de trastornar, turbar y conmover, "une machine à bouleverser le monde, ${ }^{24}$ en palabras de Aragon.

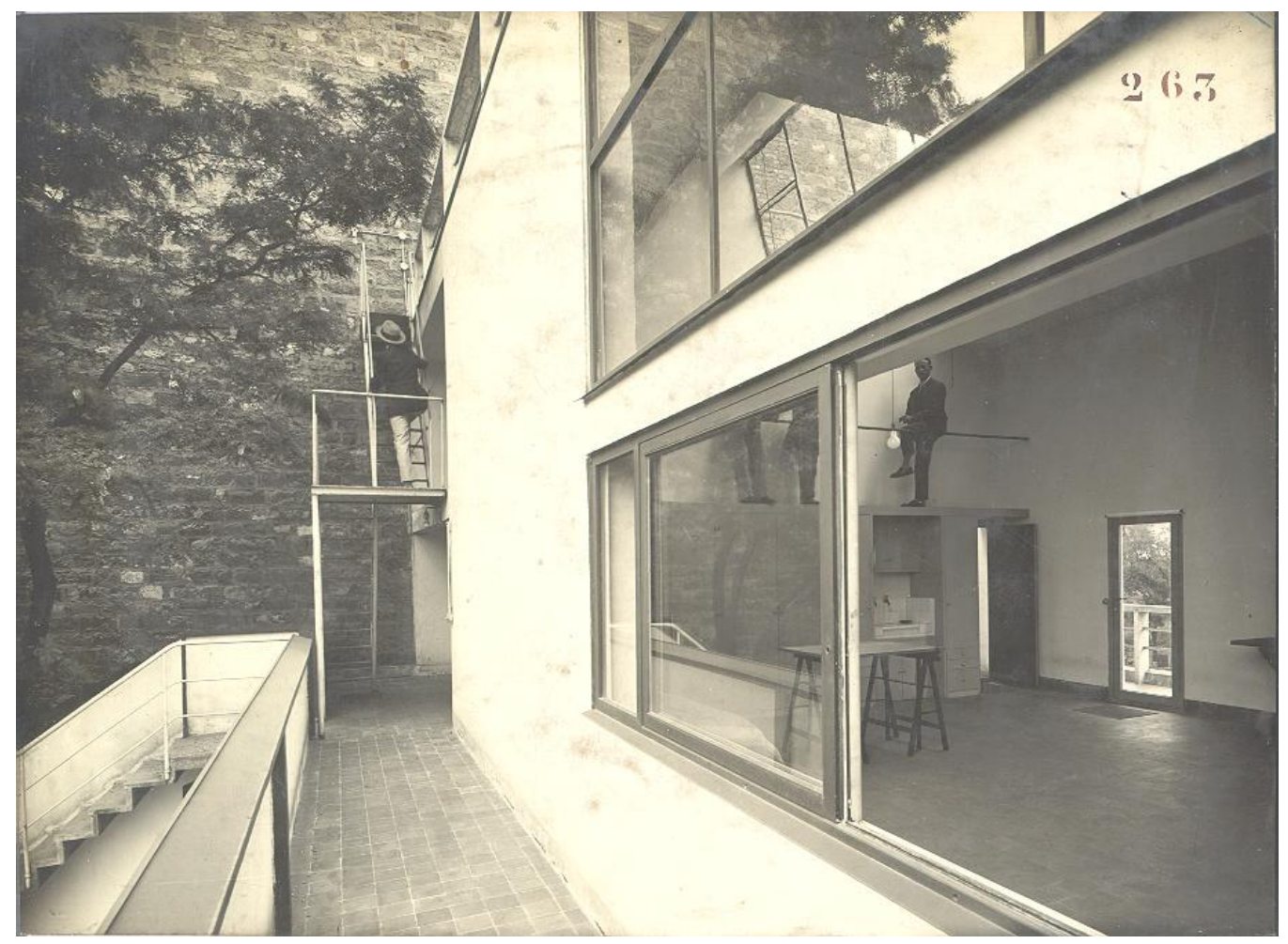

5. Le Corbusier + Jeanneret_Maison Planeix (1929) en 'L'Architecture Vivante' 3 e série, printemps, Editions Albert Morancé, París (1930) FLC-ADAGP

El ojo de Le Corbusier reproduce la misma pauta. Su mirada, intencionada y oblicua, deforma la realidad a través de las imágenes con la intención de alterar su recepción y comprensión, simulando una nueva versión a partir del original.

La fotografía de la fachada interior de la Maison Planeix (1927/29), publicada por Morancé (1930), nos introduce en un espacio confinado y sin horizonte. La sensación es la de estar en un recinto interior, confinado como una habitación. El plano vertical divide la imagen en dos partes equivalentes. A la derecha, el estudio; a la izquierda, el jardín. Como sí de una imagen especular se tratara, ambos lados se compensan en la fotografía,

\footnotetext{
24 Aragon, Louis (1923) Le grande saison Dada. Opus Internacional 123-24 (Abril-Mayo 1991), pag 109 [Una máquina de trastornar (conmover) el mundo]
} 
fomentando la idea de una duplicación, de una equivalencia intensificada por la transparencia de las ventanas. Incluso las figuras de los personajes que parecen flotar en el aire como acróbatas, elevados sobre el suelo y a la misma altura, responden a la simetría especular de un reflejo. [Fig 5]

La mirada de Le Corbusier no es frontal sino oblicua. El ojo -la cámara- se ha situado próximo a la pared, mirando simultáneamente dentro y fuera del Estudio a través de la ventana. Y debido a la oblicuidad de la mirada y su sesgada perspectiva, ambos espacios, el interior del estudio y el exterior del jardín, se perciben como semejantes, continuos e interiores.

El marco y el punto de vista anulan las diferencias, equiparándolos a pesar de sus evidentes diferencias, intensificando la simetría y la continuidad entre ambos, haciéndonos creer que podrían ser alternativamente exteriores o interiores, pero no distintos entre sí.

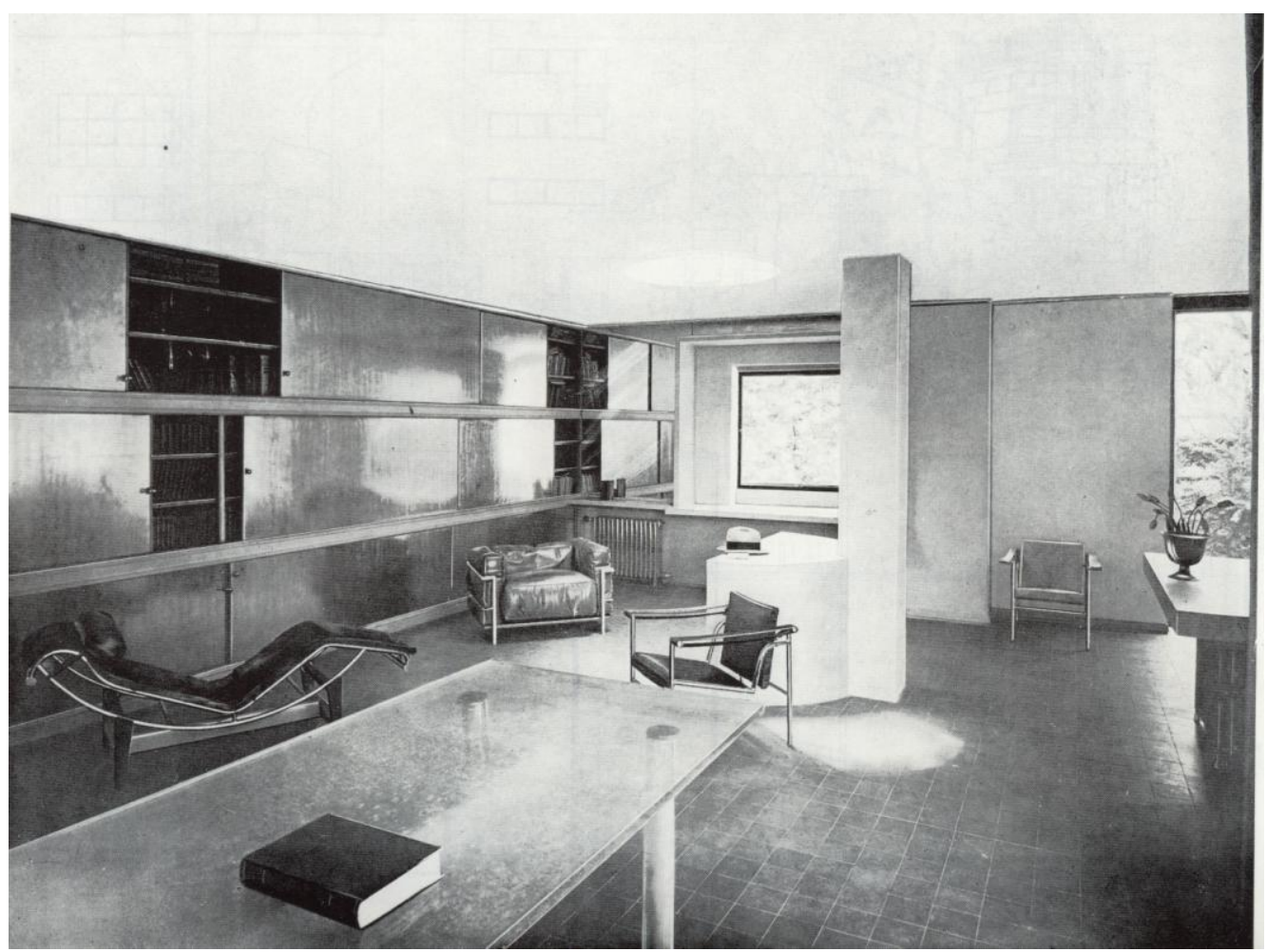

6. Le Corbusier + Jeanneret_Ville D'Avray, (1929) en 'L'Architecture Vivante' $3^{\mathrm{e}}$ série, printemps Editions Albert Morancé, París (1930) FLC-ADAGP

Si estamos ante una implementación del aforismo "el exterior es siempre un interior," ${ }^{25}$ no lo es con carácter metafórico o poético sino paradójico. Entregadas a la búsqueda de lo sublime en lo real, siguiendo la máxima de Aragon, las imágenes surrealistas no son descriptivas sino interrogativas: “...si la realidad es la ausencia aparente de contradicción, lo sublime es la manifestación de la contradicción en la realidad."

La fotografía de Maison Planeix elegida por Le Corbusier para su primera publicación en L'Architecture Vivante pertenece a la categoría de lo interrogativo, empeñada en la desestabilización de las categorías y las

25 Le Corbusier (1923): Ibid. pag 154 ['Le dehors est toujours un dedans.'] 
convenciones. La doble condición fenomenológica y conceptual simultáneamente asignada a los espacios en la fotografía -cerrados y abiertos, interiores y exteriores, continuos y discontinuos- coincide con la preferencia de Breton por aquellas imágenes que "contienen en si una enorme dosis de contradicción, sea a causa de que uno de sus términos esté curiosamente oculto...”

En la fotografía de la biblioteca de la Ville d'Avray (1928/29) publicada en la Oeuvre complète Le Corbusier intensifica de nuevo la manipulación de la realidad física a través de su reproducción fotográfica. A la derecha, un ventanal de suelo a techo sin carpintería se abre sobre el jardín. Es el paradigma de la transparencia, el 'pan de verre', el muro de vidrio por definición. Sin embargo, muy próximo y a su izquierda, una ventana rectangular -su alter ego- enmarca una vista sobre el jardín. [Fig 6]

El marco exento encuadra la imagen como si de un lienzo se tratara, y través del vidrio, la vista sobre el jardín se recorta como un paisaje tradicional. Sin embargo, en la fotografía el marco flota en la pared. Parece no tener trasera, no apoyar en una pared, no tener soporte: es, en realidad, un efecto visual, un engaño provocado por el espejo con que Le Corbusier ha empanelado la pared. Y, como consecuencia, la vista sobre el jardín a través del marco de la ventana se torna engañosa: en la fotografía, detrás de la pared no parece haber un jardín sino otra habitación -otro espacio interior-, equivalente e igual que la habitación en la que estamos.

El encuadre, cuidadosamente elegido por Le Corbusier, ${ }^{26}$ enfatiza el equívoco, aprovechando la ambigüedad para acentuar la doble condición abierta y cerrada de la habitación. En esta ocasión, un espacio interior que se 'representa como si fuera exterior', como si careciera de algunos de sus límites -el techo, la pared, etc.

Estamos ante un efecto óptico, un trompe l'œil. El prominente marco de la ventana -una representación de la ventana tradicional y una analogía de la representación pictórica-, flota artificiosamente en el espacio reflejado de la habitación como una imagen dentro de otra imagen.

La fotografía de la Biblioteca de la Ville d'Avray comparte con los collages en 'Une semaine à bonté,27 mecanismos de manipulación de la percepción, enfrentándonos a contradicciones visuales cuyo objetivo trasciende más allá de la crisis de los sistemas de representación, llegando a cuestionar la naturaleza del espacio interior o su capacidad para representar la identidad privada del sujeto. [Fig 7]

${ }^{26}$ Existen diversas versiones de esta imagen, tomadas desde diversos puntos de vista pero muy próximos entre si. Algunas revelan el engaño o trompe l'oxil y otras lo ocultan.

27 Ernst, Max (1934): Une semaine à bonté: The Original Collages. Catálogo de la exposición, Museo de Orsay, Paris 2006 


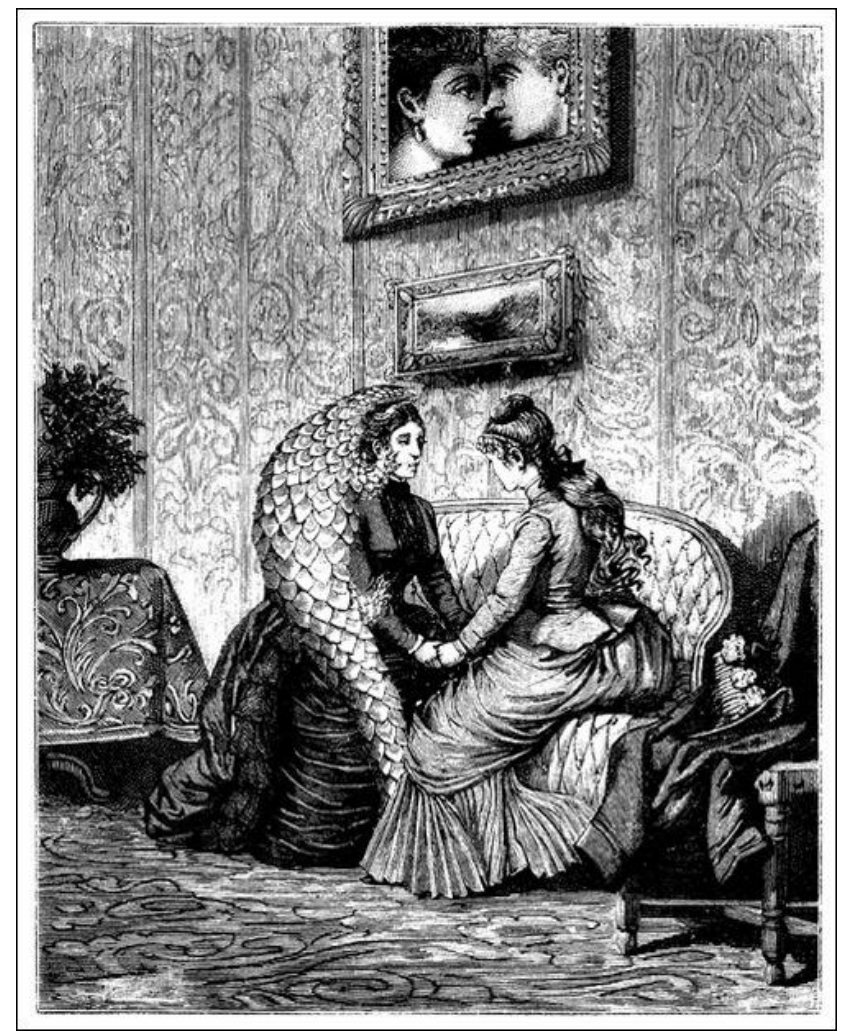

7. Max Ernst (1934), 'Une semaine à bonté, ou les sept éléments capitaux', Tercer Libro, Martes, Paris: Editions Jeanne Bucher.

En la fotografía, el espacio exterior del jardín y el espacio interior de la biblioteca se superponen en una paradoja física, pugnando por ocupar simultáneamente el mismo lugar. Y, para intensificar la ambigüedad, las líneas horizontales de la estantería y su alternancia de paneles y huecos se prolongan en la imagen reflejada, atravesando la pared y trasladándonos al otro lado de la fachada, enfrentándonos a una contradicción visual, espacial y conceptual. En palabras de Breton, una imagen será surrealista “... porque implique la negación de alguna propiedad física."

En los collages de Ernst, los lienzos enmarcados en la pared también se abren a otros espacios, a otras escenas que se suceden simultáneamente. Otras escenas tan reales o tan imaginarias como aquella en la que estamos participando. En ambos casos, Ernst y Le Corbusier, la coherencia visual ha sido destruida, interrogándonos sobre la naturaleza de las imágenes y sobre su contenido, pero también sobre las convenciones utilizadas para su construcción y comprensión.

La reproducción mecánica - la fotografía- no ha sustraído únicamente el aura a la realidad, sino también su estabilidad. Y, a través de técnicas de manipulación fotográfica, cada fragmento entra, a través de su imagen, en un proceso de edición y trastorno capaz de desfigurar su identidad.

Tal y como sugiere Breton, estas imágenes 'prestan una máscara abstracta a lo que es concreto y viceversa', Enfrentarnos a dos realidades dispares pero construidas a partir de un mismo objeto, estaríamos ante un proceso de naturaleza 'crítico paranoica' descrito por Dalí, caracterizado por la duplicación de un hecho real o de un objeto sin mediar una alteración física del mismo, tan solo de su contexto, del sistema de relaciones en el que se presenta inmerso: 
"Mediante un proceso claramente paranoico ha sido posible obtener una imagen doble, es decir, la representación de un objeto que, sin la menor modificación figurativa o anatómica, sea al mismo tiempo la representación de otro objeto absolutamente diferente, representación, esta última, que también está exenta de todo tipo de deformación o anormalidad...." 28

Si la fotografía, tal y como la emplean Brassaï o Le Corbusier, sirve no para describir el objeto sino para modificarlo, para alterar el sistema de categorías en el que se inscribe, esta puede identificarse como una técnica para producir no imágenes sino 'objetos surrealistas', cuya función es ensanchar y ampliar nuestra entendimiento de la realidad.

La desfiguración de la realidad y el trastorno de los sistemas de relaciones, ensayado inicialmente a través de la fotografía y de su manipulación, se trasladan finalmente desde la edición y manipulación de las imágenes a la realidad misma, a la arquitectura, para proponer configuraciones capaces de dislocar los sistemas de convenciones, los clichés de la arquitectura, sus fundamentos

Le Corbusier introduce el trastorno de los códigos en el corazón mismo de la arquitectura: en la configuración de la nueva domesticidad moderna. Pero, siguiendo una vez más las técnicas surrealistas -de distorsión dentro de sus límites estructurales para asegurar la comprensión de su deformación dentro de las reglas, dentro de su propia sintaxis- elige estratégicamente, para su manipulación, paradigmas característicos de lo doméstico en su tiempo: el marco, el estuche y, sobre todo, el interior.

THE PLAN OF THE MODERN HOUSE

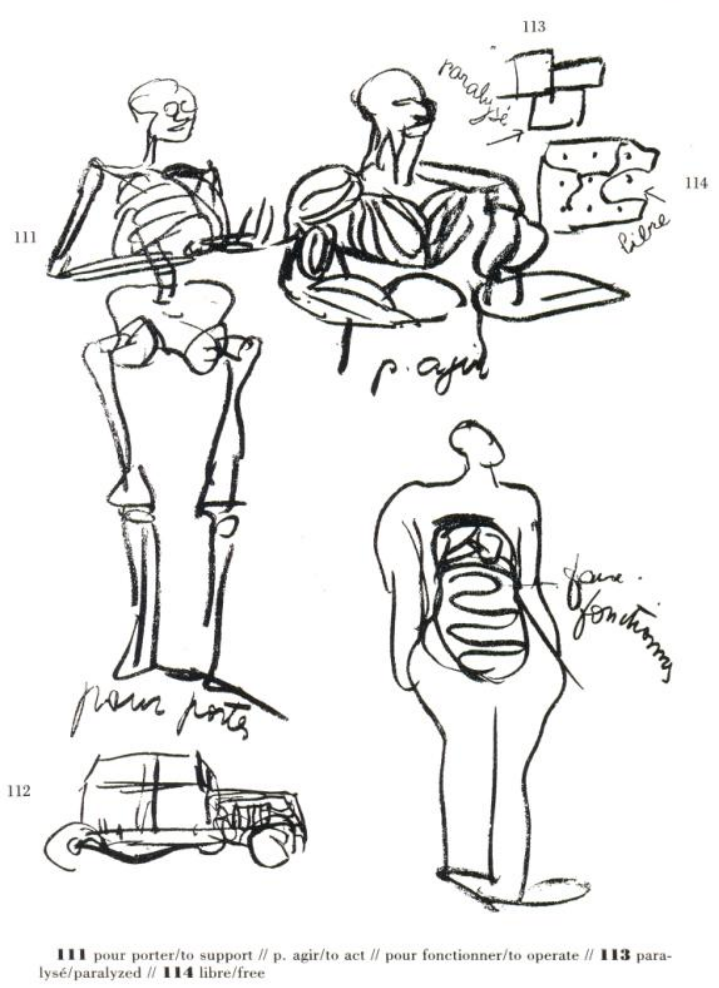

8. Le Corbusier (1930), 'Précisions...' Éditions Crès, Collec. "L'Esprit Nouveau", Paris pag 125 FLC-ADAGP

28 Dalí, Salvador: 'Interprétation paranoïaque-critique de l'image obsédante «L'Angélus» de Millet'. París: Reviste Minotaure, 1933 


\section{Conclusiones: contigüidades difíciles de resolver}

Solo en este contexto de apropiación de la paradoja como instrumento productivo, simultáneamente incubado y descubierto por el surrealismo en la ciudad, es posible entender el complejo significado asignado por Le Corbusier a los mecanismos del marco, el estuche, la estructura anatómica, el chasis o las vísceras, operativos simultáneamente en su discurso como instrumentos conceptuales y como figuras, es decir, como ideas icónicas y como objetos metonímicos.

Es el caso, por ejemplo, de las vísceras humanas, una analogía repetidamente empleada por Le Corbusier:

"Desde hace años nos hemos acostumbrado a ver plantas tan complicadas que parecen hombres que llevan sus vísceras por fuera. Nosotros defendemos que las vísceras queden dentro, clasificadas, ordenadas, que solo aparezca una masa límpida. ¡Pero no es tan fácil! A decir verdad, esa es la gran dificultad de la arquitectura: hay que poner las cosas en orden." ${ }^{29}$ [Fig 8]

El texto construye una metáfora en apariencia: la relación analógica entre las vísceras humanas, informes en sî mismas pero contenidas y limitadas dentro del orden estructural de músculos y esqueleto, y los elementos arquitectónicos del interior doméstico.

\section{CINALI}

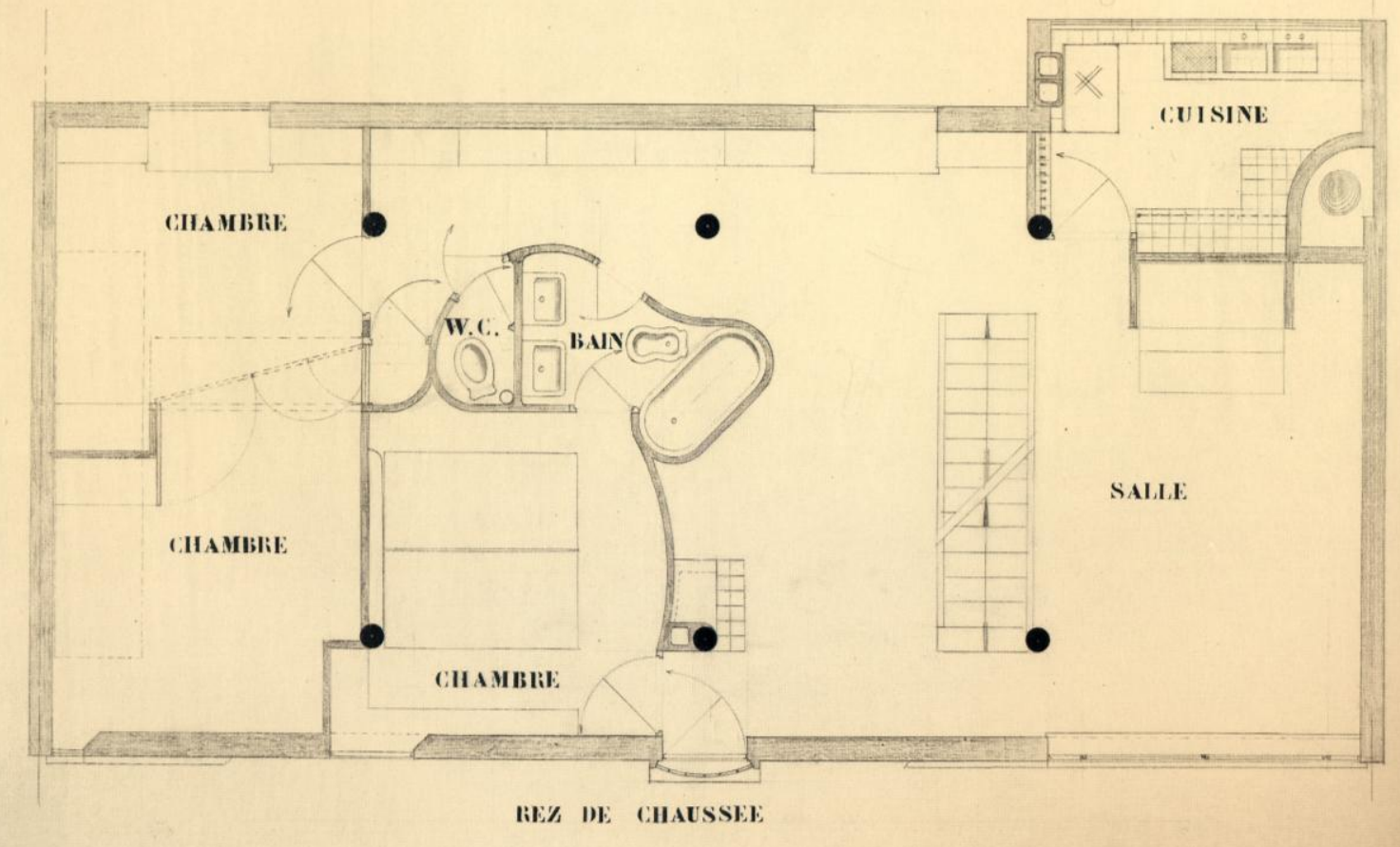

9. Le Corbusier, Planta de la Maison Canale, Boulogne-sur-Seine, 1924 FLC-ADAGP

29 Carta manuscrita enviada a Madame Meyer en octubre de 1925. Publicada en Euvre Complète Volumen 1 1910-1929. Zurich: Boessinger y Stonorov Les Editions d'Architecture, 1964. pag 89 [On est accoutumé depuis des années à voir des plans qui sont si compliqués qu'ils donnent l'impression d'hommes portant leurs viscères au-dehors. Nous avons tenu à ce que les viscères soient dedans, classés, rangés, et que seule une masse limpide apparût. Pas si facile que cela! A vrai dire c'est là la grande difficulté de l'architecture: faire rentrer dans le rang.] 
La abstracción del estuche en la caja -su transformación en un contenedor genérico y estándar, ajeno a la identidad especifica de su habitante-, se superpone con la imagen de las vísceras del cuerpo -“les viscères soient dedans, classes, rangés, et que seule une masse limpide apparû"t- que llenan el interior doméstico. Un interior que creíamos vaciado de todo rastro de identidad -de objetos y muebles, de recuerdos y souvenirs- para ser ocupado, en su lugar, por un 'equipamiento doméstico' ordenado según las leyes de la eficacia y la utilidad, y en el que ahora se dibujan las figuras simuladas de un cuerpo, una anatomía y sus vísceras.

La improbable relación entre ambos campos semánticos, así como la distancia existente entre ellos, responden a las técnicas surrealistas de desestabilización de las relaciones analógicas por medio de conexiones arbitrarias predicadas en las técnicas del montaje 'de realidades más o menos lejanas'.

Le Corbusier aprovecha el potencial de las tres figuras (esqueleto, musculatura y vísceras) como analogías disociativas capaces de construir conexiones sin un soporte semántico plausible, pero de gran efectividad icónica y conceptual. Y, por medio de la articulación fortuita de fragmentos independientes entre sí, introduce las técnicas del montaje en el centro del discurso de la arquitectura doméstica.

La planimetría de las villas Canale, Meyer y Stein de-Monzie nos sorprenden, sin embargo, con una figuración literal: las curvas y contra-curvas que rodean los aparatos sanitarios exceden el eco antropomórfico adherido a su función para contagiar a la arquitectura un parecido literal con las vísceras.

En el interior de la potente caja rectangular, el contraste entre la malla regular de pilares circulares racionalmente ubicados y las formas libres y sinuosas de las 'vísceras domésticas' no dejan lugar a dudas: si la nueva domesticidad está predicada en la lógica, esta no es ni única ni unívoca. [Fig 9]

Le Corbusier nos enfrenta abiertamente a un dilema: no a la dificultad de elegir, sino a la falta misma de necesidad de hacerlo. O, por el contrario, a la necesidad de aceptar la complejidad paradójica como un valor estructural de lo contemporáneo, su seña de identidad. Aquello que lo aproxima a nuestro tiempo y a nuestra sensibilidad.

Solo así puede explicarse que, incluso en la pequeña planta de la villa Canale (1924), se superpongan, al menos, tres lógicas: la geometría regular de la caja (el marco), la lógica estructural del hormigón armado (anatomía) y la de la continuidad espacial de la nueva domesticidad (el estuche), cada una coherente en si misma pero ajena a su articulación e integración en un sistema unitario.

Intensificadas por la inestabilidad semántica y figurativa, las figuras del marco, la anatomía del cuerpo y del estuche doméstico introducen en la arquitectura de Le Corbusier múltiples desplazamientos metonímicos. Y, precisamente por su inestabilidad y polisemia, sitúan en el centro del discurso de la 'casa moderna' las semillas de su alter ego.

La configuración de lo doméstico es, en 1920, el escenario más propicio para la escenificación del conflicto que afecta a la construcción de la identidad de la arquitectura, del individuo contemporáneo y de una unidad coherente entre ambos. Le Corbusier se implica en esta tarea de búsqueda de una domesticidad contemporánea, aparentemente predicada en la coherencia reclamada por la razón productiva asociada con la mecanización y la industrialización. En 1925 describe este proceso de cambio que, 'como un huracán', es responsable de una transformación imparable y profunda: 


\begin{abstract}
"Durante los últimos años hemos asistido a las sucesivas etapas de un acontecimiento: con la construcción metálica, la disociación entre la decoración y la estructura. Luego la moda de destacar la construcción, indicadora de la nueva formación. Luego, la admiración por la naturaleza, revelando el deseo de reencontrar (a través de que extraño rodeo!) las leyes de lo orgánico. Finalmente, la manía por lo sencillo, el primer contacto con las verdades de la máquina, llevándonos de vuelta al sentido común y a la instintiva manifestación de una estética de nuestra era." 30
\end{abstract}

Sin embargo, la presencia decisiva de objets à réaction poétique - a menudo asimilables por su función icónica a objets trouvés surrealistas- que alteran la estabilidad de las imágenes y de su reivindicada abstracción sugiere un uso de las técnicas del shock y la contradicción de modo consistente e intencionado.

Así se pone de manifiesto, por ejemplo, en el diagrama de la 'Planta Libre' o en las plantas de la Villa Stein deMonzie, por ejemplo. El conflicto inscrito en el dibujo planimétrico trasciende los problemas de la representación y nos enfrenta a la difícil convivencia entre el espacio fluido y la arquitectura de las habitaciones. El conflicto de su 'superposición sobre un único soporte', expresado a la manera de Ernst.

El proceso de concepción, dibujo y construcción de la villa Stein-de Monzie (1927) tiene un particular interés no solo por la complejidad en su programa -puede describirse alternativamente como una vivienda compartida o como dos viviendas unidas-, sino también porque representa el ensayo más riguroso y complejo de los paradigmas manejados por Le Corbusier en la década de 1920/30 y la gestión del conflicto. [Fig 10]

"Al interior, la planta es libre, cada piso tiene una distribución totalmente independiente, rigurosamente adaptadas a unas funciones específicas: las separaciones no son más que membranas. La impresión de riqueza no la proporciona el lujo de los materiales, sino simplemente la disposición interior y sus proporciones. Toda la casa obedece a los trazados reguladores que condujeron a modificar, a la medida de $1 \mathrm{~cm}$., las dimensiones de cada partición. La matemática aporta aquí verdades reconfortantes: dejamos su obra con la certeza de haber llegado a la cosa exacta." 31

\footnotetext{
${ }^{30}$ Le Corbusier (1925): L'Art décoratif d'aujourd'hui. París: Editions G. Crès, 1925

31 Le Corbusier. Descripción de la Villa Garches (1927) en Euvre complète Vol 1 1910-1929, Zurich : W. Boessinger y O. Stonorov Les Editions d'Architecture, 1964. pag 144
} 


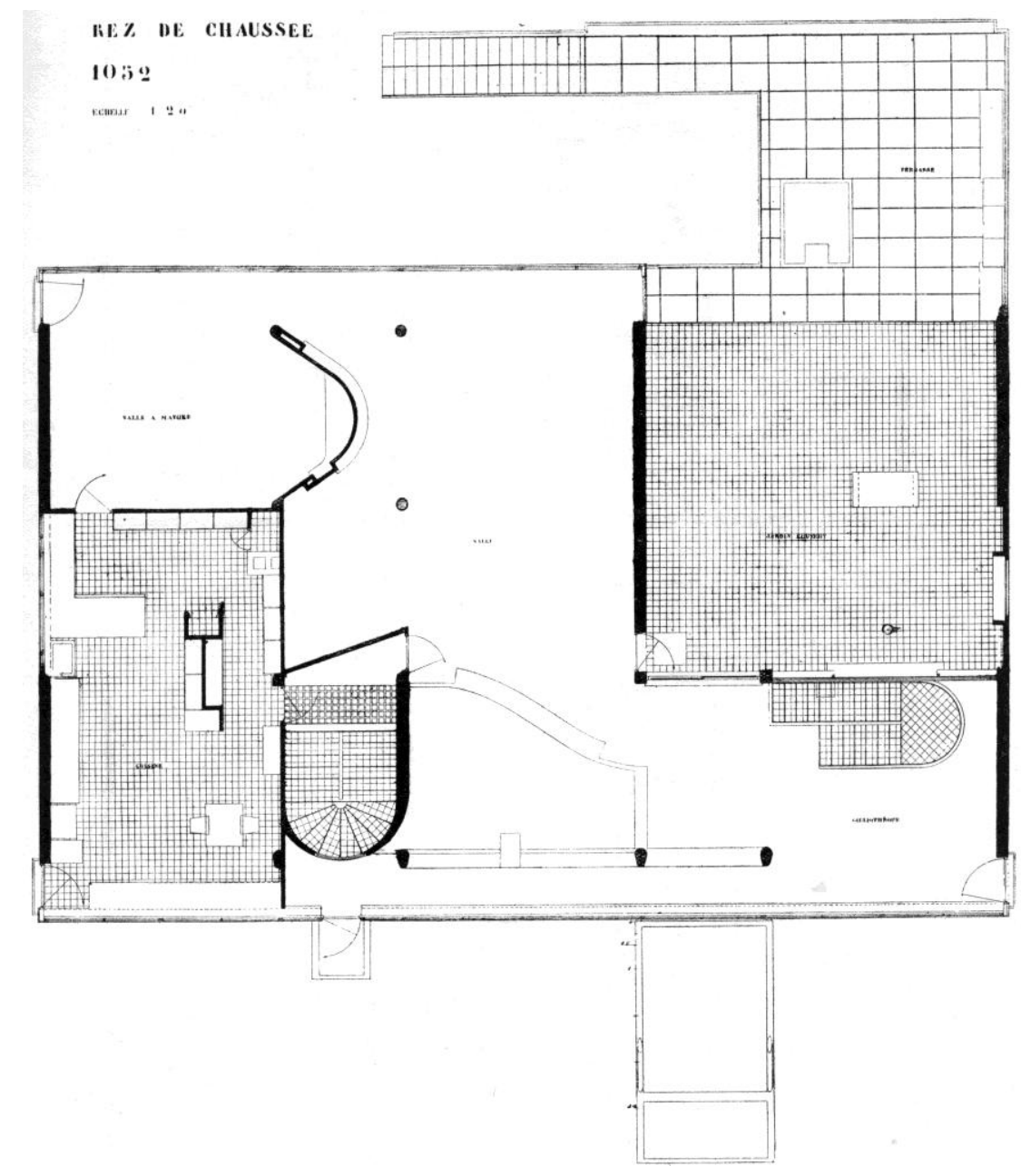

10. Le Corbusier, Planta de la Villa Stein De-Monzié, Garches, 1927 FLC-ADAGP

Aunque propone confiar la coherencia formal, estructural y espacial de la Villa Stein-de Monzie a la proporcionalidad armónica inscrita en los trazados reguladores, el orden matemático es sólo uno de los medios puestos en práctica para alcanzar una unidad que lo es solo en apariencia. Una unidad amenazada por la constante distorsión introducida por la potencia icónica de las figuras derivadas de la especificidad funcional, el respeto de convenciones domésticas propias de la clase social de los Stein y de la señora de Monzie -asociadas a la privacidad del mundo femenino y a una idea de lujo entendido como bienestar físico del cuerpo- pero, sobre todo, por la continua articulación implementada para encadenar la experiencia del interior en una secuencia capaz de restaurar la unidad.

El conflicto advertido por Tafuri entre los objets à réaction poétique -icónicos por definición- y la abstracción derivada del vaciamiento propio de la planta libre, junto con la distorsión diagonal y escenográfica impuesta por una circulación panorámica que recorre la casa, condicionan la estabilidad y dificultan la unidad prometida. Simultáneamente plano y profundo, único y estratificado, continuo y fragmentario, el espacio de la villa Stein-de Monzie acoge cualidades dispares y contrapuestas, no tan diferentes de las que agitan los collages de Ernst o de los montajes de Picasso. 


\begin{abstract}
"Señora", escribe Le Corbusier, "hemos soñado con haceros una casa que fuera tersa y uniforme como un cofre de bellas proporciones y a la que no ofendieran los múltiples accidentes que crean un ambiente pintoresco, artificial e ilusorio y que rechinan bajo la luz, añadiendo más ruido al ruido. Nosotros nos oponemos a la actual moda que castiga a este país y en el extranjero de casas complicadas e hirientes. Pensamos que la unidad es más fuerte que las partes. Y no crea usted que la simplicidad es fruto de la pereza; por el contrario, es el resultado de un plan largamente madurado. Lo simple no es fácil." 32
\end{abstract}

La afirmación 'nous pensons que l'unité est plus forte que les parties' señala un punto de inflexión y nos orienta sobre las diferencias entre la volumetría agregada de la Maison la Roche y la forma rotunda y compacta que caracteriza las villas Meyer, Cook y la que nos ocupa.

Las tensiones espaciales, programáticas y estéticas se ven definitivamente confinadas dentro de un volumen abstracto y regular, y un entramado estructural igualmente abstracto y regular. Las 'vísceras' del organismo doméstico vuelven al interior del cuerpo, ordenadas y clasificadas. La compresión hacia el interior -la interiorización total del programa domestico dentro del cofre, de un estuche en la terminología de Benjaminobliga no solo a reordenar los elementos y reconsiderar sus jerarquías sino, y más importante, a aproximar elementos dispares, fomentando la continuidad en la contigüidad, 'trabajando a favor de la unidad aparente y en contra de la fragmentación pintoresca'.

Sí el marco y el orden estructural imponen una unidad abstracta, la distribución interior, por agregación de elementos independientes, construida por acumulación de incidencias, es ajena a un principio unitario. Incluso la terraza/jardín deja de ser el elemento central, diferenciador y articulador entre los dos apartamentos, para transformarse en una 'habitación interior' mas, engarzada en la secuencia de contigüidades que intentan conciliar la fragmentación en habitaciones y espacios interiores privados y la continuidad de un recorrido interior panorámico que articula las múltiples vicisitudes en una secuencia, como si de del movimiento por un jardín, un paisaje o una ruina se tratara.

La imposición del marco - de una envolvente regular y abstracta- es una decisión radical: un límite geométrico y sin accidentes que obliga a contener en su interior todos los elementos y sus relaciones. Una vez tomada esta decisión, toda la arquitectura será interior; y, del mismo modo, todas las relaciones serán de intensa contigüidad dentro de los límites del marco.

"Para que surja la poesía de estos temas arquitectónicos son necesarias contigüidades claras difíciles de resolver." 33

El espacio se construye como articulación de las piezas autónomas, de los fragmentos. Una articulación que nos obliga a circular entre y alrededor de las piezas para re-construir una unidad -un sistema de relaciones- cuya presencia intuimos pero que no es legible. Una experiencia accidentada y discontinua que debe ser reconstruida uniendo los fragmentos por medio de las técnicas del montaje. Una dificultad a la que hace referencia C. Rowe

32 Carta manuscrita de Le Corbusier, enviada a Madame Meyer en Octubre de 1925. Publicada en Euvre complète Volumen 1 1910-1929. Zurich: Boessinger y Stonorov Les Editions d'Architecture, 1964. pag 89

33 Le Corbusier (1964): Euvre complète Volumen 1 1910-1929 Zurich: Boessinger y Stonorov Les Editions d'Architecture, 1964. pag 89 
(1947) cuando afirma que conceptualmente todo está claro pero, desde el punto de vista de la experiencia, es profundamente paradójico.

En definitiva, Le Corbusier potencia iconos distintivos del mundo doméstico -formas antropomórficas y figuras reconocibles asociadas con la domesticidad y la privacidad- paradójicamente inscritos en espacios abstractos, manipula las técnicas del poché para resolver las necesidades de la domesticidad contemporánea en una planta abierta y sin compartimentación, e intensifica la interiorización del espacio privado al tiempo que potencia la continuidad espacial asociada con el movimiento.

Se apropia igualmente de la inversión entre lo doméstico y lo público por medio de la exacerbación de la circulación -de la experiencia fragmentaria del interior-, como si de un recorrido a lo largo de una ruina o un paisaje se tratara. Predicado en el movimiento, el espacio doméstico se abre necesariamente y, al hacerlo, expone el conflicto entre continuidad y discontinuidad o entre transparencia y compartimentación.

Al igual que ocurre en los montajes de Max Ernst, los espacios domésticos construidos por Le Corbusier entre 1920 y 1935 se debaten entre la unidad y la fragmentación, entre la envolvente geométrica que encierra y protege el espacio privado del interior y la fluidez espacial del recorrido que abre la casa al exterior y la transforma en un paisaje.

Un debate latente que no solo no concluye ni se resuelve, sino que se potencia y aprovecha.

Aunque la racionalización y la industrialización a la que hace constante referencia son responsables de una transformación profunda, lo que distingue la arquitectura de Le Corbusier es el atrapamiento entre ambos modelos espaciales y domésticos: su superposición. En la arquitectura de Le Corbusier, el espacio doméstico es simultáneamente abierto y envolvente, transparente y compartimentado, continuo y discontinuo. O, en sus palabras, interior y exterior. Es, por tanto, conflictivo por definición o, en palabras de Breton, sublime y, por tanto, ajeno a la simplificación racional o a la ley de 'la causa y el efecto'.

Para los surrealistas, la manifestación de los aspectos sublimes de la realidad requiere la presencia simultánea del paradigma y de su deformación, de su forma estable y su fractura. Sea este paradigma el lenguaje -garante de la coherencia semántica por medio de la estructura sintáctica-, el marco -el mecanismo para diferenciar la realidad de su representación- o la estructura anatómica -sobre cuya apariencia se sustenta la naturalidad orgánica o, al menos, se representación.

"Rather than reducing the disjunctions of the parts, the englobing term as stage, frame, box or anatomy simple displays the merveilleux as a space of paradox. Such dissociative metonymies tease the imagination without ultimately yielding to the cognitive process of decoding." 34

34 Adamowicz, Elza: Surrealist Collage in Text and Image. Dissecting the exquisite corpse. Cambridge University Press, 1998. pag 83 
En una improbable aunque innegable coincidencia con el surrealismo, Le Corbusier aprovecha los conflictos latentes para construir un discurso más ambicioso que el de la razón, superponiendo estrategias e instrumentos contrapuestos. Y la sensibilidad surrealista que invade la experiencia de Paris en los años de la posguerra le ofrece los recursos para integrar el conflicto en el discurso de la arquitectura como conexiones improbables e imprevistas entre 'realidades más o menos lejanas'.

\section{Bibliografía}

Adamowicz, Elza: Surrealist Collage in Text and Image. Dissecting the exquisite corpse. Boston, MASS: Cambridge University Press, 1988

Aragon, Louis: Los collages. El desafío a la pintura. Madrid: Editorial Síntesis, 1930

Aragon, Louis: Le grande saison Dada. Opus Internacional 123-24. París: s.e. 1923

Breton, André: Manifeste du surréalisme. Paris: Gallimard, 1924. Traducción: Manifiestos del Surrealismo. Madrid: Visor Libros, 2002

Breton, André: Ouvrés complètes II. París: Gallimard, 1992

Breton, André: Surréalisme et la peinture. París: Editions Gallimard, Paris 1928 (2 Ed. 1965). Surrealism and Painting Boston: MFA Publications, 2002

Brotchie, Alastair: A book of Surrealist games. Londres: Redstone Press, 1991

Dalí, Salvador: “Interprétation paranoïaque-critique de l'image obsédante «L'Angélus » de Millet”, Reviste Minotaure. París, 1933

Eluard, Paul: "Sur certaines possibilités d'embellissement irrationnel d'une ville", Surréalisme au Service de la Révolution $n^{\circ}$ 6. París, 1933

Ernst, Max (1934): Une semaine à bonté: The Original Collages. París: Catálogo de la exposición, Museo de Orsay, 2006

Foucault, Michel (1973): Ceci n'est pas une pipe. Montpellier: Fata Morgane, 1973. Tradución: Esto no es una pipa. Barcelona: Editorial Anagrama, 1981

Le Corbusier: Une Maison-une Palais. París: Editions Convences, 1928

Le Corbusier: Vers une architecture. París: Flammarion, 1923

Le Corbusier: L'Art décoratif d'aujourd'hui. París: Editions G Cres, 1925

Le Corbusier: Euvre complète Volumen 1 1910-1929. Zurich: Boessinger y Stonorov Les Editions d'Architecture, 1964

Lucien Duchase, Isidore, Conde de Lautréamont (1896): Los Cantos de Maldoror. Madrid: Editorial Pretextos 2000

Reverdy, Pierre: Nord-Sud Marzo. París, 1918

Vaseley, Davilor: “Surrealism and Architecture”. Architectural Design nº 5\&6, London UK, 1978

Vidler, Anthony (2003): "Fantasy, the Uncanny and Surrealist Theories of Architecture", keynote speech given at the conference "Fantasy Space: Surrealism and Architecture", Manchester, Whitworth Art Gallery, September 12, 2003. UK

Vidler, Anthony: The Architectural Uncanny: Essays in the Modern Unhomely. Cambridge, MASS: MIT Press, 1992 